\title{
PENDIDKAN KARAKTER DALAM BINGKAI PENDIDIKAN ISLAM: \\ Studi di Pondok Pesantren Al-Halimy Sesela, Lombok Barat
}

\section{Johairi $^{*}$}

\begin{abstract}
Abstrak: Pendidikan karakter di Pondok Pesantren sangatlah penting dilakukan, sebab hal tersebut dapat menjadikan siswa atau santri mengalami perubahan, baik sikap, prilaku, dan pola fikir serta kepribadian yang luhur. Artikel ini bertujuan untuk mendiskusikan penanaman karakter peserta didik/santri di Podnok Pesantren AlHalimy Sesela, Gunungsari, Lombok Barat. Pondok pesantren AlHalimy merupakan salah satu lembaga pendidikan di Kabupaten Lombok Barat yang mengambil peran dalam penanaman pendidikan karakter atau akhlak.
\end{abstract}

Kata Kunci: pendidikan karakter, nilai, disiplin, tanggujawab, toleransi, pondok pesantren Al-Halimy Sesela.

\section{Pendahuluan}

7 endidikan adalah sebuah proses jati diri seseorang peserta didik untuk lebih maju. Nilai-nilai pendidikan sendiri L adalah suatu makna dan ukuran yang tepat dan akurat yang mempengaruhi adanya pendidikan itu sendiri.Adapun pemerintah Indonesia menggaung-gaungkan pendidikan karakter dengan diterbitkannya UU No 20 tahun 2003 tentang tujuan pendidikan nasional.Islam telah mengajarkan pendidikan karakter dan penanaman budi pekerti dengan gamblang. Karakter sama dengan akhlak dalam pandangan Islam.Akhlak dalam pandangan Islam adalah keperibadian. Keperibadian itu komponennya ada tiga yaitu pengetahuan, sikap, dan prilaku.Yang dimaksud dengan kepribadian utuh adalah apabila pengetahuan sama dengan sikap dan sama dengan prilaku (Majid, dan Andrayani, 2011:58). Implementasi akhlak dalam Islam tersimpul dalam kepribadian

* Mahasiswa Pascasarjana UIN Mataram, email: johairiher@ymail.com 
Rasulullah SAW. Sebagaimana termaktub dalam hadist yang yang berbunyi:

\section{إ نما تثعب ذلأمم كمامر الأخلاق}

Artinya: Sesungguhnya aku diutus untuk menyempurnakan akhlak yang mulia (HR. Ahmad).

Hadist ini menunjukan bahwa betapa pentingnya pendidikan karakter atau akhlak untuk diterapkan di sekolah formal atau non formal.Dalam hal ini penggalian pendidikan karakter bisa didapatkan pada refrensi-refrensi klasik dan salah satu refrensi klasik yang membahas tentang itu adalah kitab Al-Akbläk Lil Banin Jilid Pertama yang dikarang oleh Al-Ustadz 'Umar Bin Ahmad Baraja yang berisi tentang pembagian pendidikan karakter atau akhlak dibagi menjadi dua: Pertama Akhlaq kepada Allah dan Rasulullah SAW dan kedua akhlak kepada sesama manusia.Akhlak kepada sesama manusia ini dibagi lagi kedalam akhlak kepada orang tua, guru, saudara, teman, kerabat, tetangga, dan pembantu. Kemudian berbicara masalah karakter tentunya memiliki banyak istilah seperti watak,tabi'at, atau akhlak,sehingga karakter atau akhlak dalam kontek teologis dan konstitusi kita sudah mengatur dengan sangat sistimatis betapa esensialnya sebuah pendidikan karakter atau akhlak itu sendiri. Kemudian dalam terminologi Islam istilah karakter disamakana dengan khuluq (bentuk tunggal dari akhlaq),yang didefinisikan sebagai kondisi batiniah(dalam) dan kondisi lahiriah(luar) manusia (Ramayulis, 2010:214).

Karakter sebagaimana dikatakan oleh Yanthi dalam Salahudin adalah watak, tabiat, akhlak, atau kepribadian seseorang yang terbentuk dari hasil internalisasi berbagai kebajikan yang diyakini dan digunakan sebagai landasan cara pandang,berfikir,birsikap dan bertindak (Salahudin, 2013:44). Sehingga dengan demikian karakter atau akhlak merupakan aspek yang sangat penting dalam kehidupan manusia. Namun kita melihat dewasa ini gejala kemerosotan akhlak sudah benar- benar menghawatirkan kejujuran, kebenaran, keadilan, tolong menolong, dan kasih sayang antar sesama sudah tertutup oleh kebohongan, saling menipu, merugikan dan saling menzolimi 
dan tidak saling menghargai antara yang besar dengan yang kecil dan antara guru dengan murid.Kemerosotan akhlak itu terjadi bukan saja menimpa orang dewasa tapi menimpa para santri atau siswa di pondok pesantren.

Pendidikan karakter bertujuan untuk menigkatkan mutu penyelenggaraan dan hasil pendidikan di Sekolah atau di Pondok Pesantren yang mengarah pada pencapaian pembentukan karakter dan akhlak mulia peserta didik secara utuh,terpadu dan seimbang. Melalui pendidikan karakter diharapkan peserta didik mamapu secara mandiri meningkatkan dan menggunakan pengetahuannya, mengkaji dan menginternalisasi serta mempersonalisasi nilai-nilai sehingga terwujud dalam prilaku sehari-hari di sekolah atau di pondok pesantren (Sofan Amri, 2011:31). Dalam tilikan sejarah, pondok pesantren telah, sedang, dan terus akan menjadi cagar budaya yang menjadi benteng untuk mempertahan nilai-nilai pendidikan karakter, keindonesiaan, keislaman dan kemanusiaan. Telah jamak dipahami bahwa ada tiga rukun pondok pesantren: kyai, santri dan masjid berinteraksi dalam pengamalan yang utuh terhadap nilai-nilai Islam yang dalam proses pembelajarannya terus diinternalisasi agar menjadi karakter yang kokoh dari setiap individu santri. Meskipun tingkat kekokohan karakter itu naik turun seiring faktor-faktor luar yang mempengaruhi, fungsi pendidikan karakter di pondok pesantren terus berjalan karena demikianlah memang karakter dasar pendidikan di pondok pesantren.

Adapun pondok pesantren Al-Halimy merupakan salah satu lembaga pendidikan yang terletak di Dusun Sesela Kecamatan Gunung Sari Kabupaten Lombok Barat mengambil peran dalam penanaman pendidikan karakter atau Akhlak namun demikian masih banyak santri yang memiliki akhlak yang buruk. sehingga respon masyarakat di lingkungan pondok pesantren Al-Halimy tersebut masih bervariasi terkait akhlak yang dimiliki para santri. Respon masyarakat ini sangat beralasan karena berdasarkan observasi awal yang peneliti lakukan di lingkungan pondok pesanten, para santriwan dan santriwati ketika melakukan sholat duha,sholat dzuhur berjamaah sebelum pulang, kuliah tujuh menit 
(kultum) selesai shalat muhadarah mingguan, dan bermudzakarah dengan teman-temannya mereka iringi dengan ketidak seriusan atau main-main,dan ketika mereka disuruh menghafal pelajaran oleh guru mereka justru mereka enggan untuk menghafal dan sedikit sekali yang masuk pada waktu menghafal (Observasi,tanggal 17 Februari 2016).

Secara filosofis, pembangunan karakter bangsa merupakan sebuah kebutuhan asasi dalam peroses kehidupan bangsa karena hanya bangsa yang memiliki karakter dan jati diri yang kuat dan eksis. Secara ideologis, pembangunan karakter merupakan upaya mengejawantahkan ideology Pancasila dalam kehidupan berbangsa dan bernegara. Secara normatif, pembangunan karakter bangsa merupakan wujud nyata langkah mencapai tujuan bangsa,yaitu meliindungi segenap bangsa Indonesia dan seluruh tumpah darah Indonesia, mewujudkan kesejahteraan umum, mencerdaskan kehidupan bangsa, ikut melaksanakan ketertiban dunia berdasarkan kemardekaan, perdamaian abadi, dan keadilan sosial.Secara historis, pembangunan karakter bangsa merupakan sebuah dinamika inti proses kebangsaan yang terjadi tanpa henti dalam kurun sejarah,baik zaman penjajahan maupun zaman kemardekaan, dan secara sosiokultural,pembangun karakter bangsa merupakan suatu keharusan dari suatu bangsa yang multi kultural.

\section{Pengembangan Keperibadian}

\section{Kejujuran}

Kejujuran merupakan salah satu karakter yang dikembangkan di Pondok Pesantren Al-Halimy Sesela Gunung Sari Lombok Barat,dimana kejujuran merupakan satu hal yang sangat penting dalam pembentukan karakter santri, bagaimana pun kecerdasan yang dimiliki oleh santri jika tidak dibarengi dengan nilai kejujuran maka tidaklah memiliki arti apa pun, sehingga dalam pengembangan karakter santri, penanaman nilai, kejujuran di pondok pesantren AlHalimy Sesela cukup menjadi perioritas utama dalam proses 
pembelajaran. Sebagaimana yang dikatakan oleh usatad Zainuddin dalam memaknai kejujuran sebagai berikut:

"Dalam kehidupan ini yang paling penting adalah kejujuran dan akhlak muliya, bagaimana pun tinggi sekolah dan gelar yang kita sandang tanpa adanya sifat jujur dan akhlak muliya maka semua itu akan menjadi hampa tanpa bermakna apa-apa, lebih-lebih dalam pandangan masyarakat tidak melihat sejauh mana dan setinggi apa sekolah seseorang tetapi yang dilihat bagaimana akhlak dan kejujuran seorang tersebut. Untuk itu lah kami dipondok ini selalu menekankan pada santri untuk berlaku jujur dalam kehidupan sehari-hari baik kehidupan pondok maupun diluar pondok"

Santri pondok pesantren Al-Halimy Sesela dalam meperaktikkan nilai-nilai kejujuran dalam kehidupan sehari-hari sangat tampak dari perilaku yang ditunjukkan dalam peroses belajar mengajar setiap harinya, misalkan ketika slah seorang ustad/ustadzah memberikan amanah untuk menyelesaikan suatu tugas.

\section{Tangoung Jawab}

Begitu juga halnya dengan tanggung jawab, menjadi bagian dan tidak kalah pentingnya dalam pengembangan karakter santri, santri terus dilatih untuk memiliki rasa tanggung jawab yang tinggi dalam setiap tugas dan kewajibannya sebagai santri di pondok pesanteren Al-Halimy Sesela Lombok Barat.Mulai dari hal-hal terkecil misalnya membuat pekerjaan rumah (PR) yang dibebankan oleh masingmasing ustad/ustadazah yang bersangkutan harus dikerjakan tepat waktu tanpa terkecuali.Kemudian dalam konteks kewajiban sebagai santeri misalnya, harus mentaati peraturan ponpes, berpakaian rapi sesuai dengan seragam yang sudah ditentukan oleh pondok juga harus dipatuhi dengan rasa tanggung jawab oleh seluruh santri tanpa terkecuali.

Tangung jawab tidak hanya dalam konteks belajar mengajar, tetapi para santri juga dituntut untuk selalu memiliki rasa tanggung jawab atsa semua hal yang mereka lakukan. Baik yang berkaitan dengan kehidupan pondok maupun diluar pondok pesanteren.Penanamaan rasa tanggung jawab terhadap santri 
tentunya bukan hall yang mudah dan gampang,tetapi butuh waktu dan latihan secara terus menerus, melalui berbagai program dan teladan dari para ustadz/ustadzah dan para pengasuh pondok pesantren salah satu bentuk penanaman rasa tanggung jawab yang selalu dicontoh kan oleh para pengasuh pondok pesantren tergambar dalam rekaman wawancara yang peneliti lakukan yaitu:

"Dalam hal menanamkan rasa tanggung jawab kepada para santri, kami selaku pengelola pondok pesantren selalu memberikan contoh nyata dan sederhana sehingga mudah untuk diikuti oleh para santri, kami tidak mau memberikan janji-janji yang muluk yang justeru tidak bisa mereka jangkau, ini kan menjadi hal yang sia-sia, dengan demikian kami berprinsip untuk melakukan hal sederhana tapi syarat dan makna. Kami berpandangan bahwa ketika semua santri memiliki rasa tanggung jawab atas semua tugas dan kewajibannya selaku santri maka kami selaku pengelola beranggapan tidak akan kerepotan dalam melakukan pengawasan secara intens terhadap para santri"

Selanjutnya pondok pesantren Al-halimy Sesela Gunung Sari Lombok Barat mengembangkan karakter santri melalui pembentukan rasa tanggung jawab yang tinggi,dengan sistem dan proses yang tentunya tidak instan, proses itu dilakukan secara kontinyu dan melalui tahapan-tahapan sesuai perkembangan santri yang bersangkutan. Para santri diajarkan nilai tanggung jawab melalui tugas-tugas sederhana yang harus diselesaikan tepat waktu sesuai dengan kesepakatan,jika ada yang tidak mentaati atau tidak menyelesaikan maka mereka dituntut untuk mempertanggung jawabkan kesalahannya itu, dalam konteks ini ada dua nilai sekaligus yang diterapkan yaitu nilai tanggung jawab dan keadilan,artinya dengan diterapkannya hukuman bagi yang tidak mengerjakan tugas maka mereka akan berpikir bahwa tidak ada perbedaan antara mereka, bahwa mereka sama-sama membedakan hanyalah kepatuhan terhadap hukum dan tata tertib yang sudah berlaku. Menurut pengakuan salah seorang santri wati yang pencilit mewawancarai sebagai berikut

"Kalau masalah bertanggung jawab,kami semua selalu dilatih dan diajarkan oleh para ustadz/ustadzah kami di sini, terutama setiap pagi hari kami selalu mendengarkan siraman rohani melalui ceramah yang disampaikan baik oleh ustadz maupun temen-temen kami secara 
bergantian setiap harinya. Ustadz selalu menekan kan kepada kami semua untuk selalu bertanggug jawab atas setiap tugas atau amanat yang kami emban, apalagi kami selaku pengurus OSIS, dituntut untuk lebih memberikan contoh kepada teman-teman yang lain sebagaimana berlaku adil dan tanggung jawab. Makanya setiap perintah dari ustadz kami selalu berusaha untuk menyelesaikannya dengan penuh tanggung jawab, waalaupun hasilnya mungkin belum maksimal, tetapi paling tidak kami sudah melakukannnya"

Tanggung jawab ini merupakan sikap saling membutuhkan satu sama lainnya sehingga terbangunlah kerjasama yang baik antar sesame begitu juga halnya dengan peraktek yang terjadi dalam lingkungan pondok pesantren Al- Halimy Sesela Gunung Sari Lombok Barat berdasarkan hasil pengamatan yang peneliti lakukan, terlihat bahwa antara santri terlihat kompak dalam melaksanakan setiap tugas yang dibebankan pada mereka, seperti membersihkan halaman bermain secara bersama-sama, merapikan buku perpustakaan setelah selesai membacanya, dan mengumumkan barang temuan melalui sumber imformasi.

\section{Rasa Hormat}

Menghormati atau menunjukkan penghargaan pada orang lain merupakan suatu tindakan yang sangat terpuji, sehingga pondok pesantren Al-Halimy Sesela Lombok Barat memandang pentingnya rasa hormat sebagai salah satu unsur karakter yang perlu dikembangkan atau diimplementasikan dalam mewujudkan santri yang berkarakter.Ketika semua santri memiliki rasa hormat yang tinggi kepada semua orang maka tujuan terselenggaranya pendidikan pesantren akan terwujud dengan maksimal.Realitas perilaku para santri berdasarkan pengamatan mendalam yang peneliti lakukan selama peelitian, cukup menunjukakan bahwa rasa hormat yang dimiliki oleh para santri memang jadi khas tersendiri bagi santri, setiap santri bertemu atau berpapasan dengan para ustadz dan ustadzhnya mereka selalu mengucapkan salam dan berjabat tangan sembari mencium tangan ustadz dan ustadzahnya secara bolak balik. 
Perwujudan rasa hormat yang ditunjukkan oleh para santri ternyata sudah tertanam sejak mereka menginjakkan kaki di Pondok Pesantren Al-Halimy Sesela Lombok Barat, perilaku tersebut merupakan bagian dari keharusan bagi mereka dalam bertingkah laku dalam pondok pesantren. Berdasarkan hasil wawancara yang peneliti tangkap sebagai berikut:

"ya memang sejak awal kita sudah menanamkan sifat untuk saling menghormati pada para santri, termasuk juga bagaimana mereka menghormati semua ustadz/ustadzah yang ada disini, dan sudah kita biasakan setiap bertemu saling mengucapkan salam dan berjabat tangan, tidak hanya kepada ustadz saja tetapi kepada sesame santri juaga harus saling mengucapkan salam dan berjabat tangan setiap ketemu dimana saja tidak hanya dalam lingkungan pondok pesantren saja, terlebih diluar pondok pesaantren, mereka harus menunjukkan akhlak yang mulia supaya bisa menjadi contoh dilingkungan mereka masing- maasing"

\section{Kedisiplinan diri}

Hasil suatu pendidikan dapat dilihat dari lingkungan pondok pesantren maupun dalam lingkungan masyarakat sekitar pondok pesantren. Perwujudan perilaku santri dalam lingkungan pondok pesantren merupakan cerminan dari niilai kedisiplinan yang sudah diterappkan oleh pengelola pondok pesantren. Maju atau mundurnya suatu lembaga pendidikan tidak terlepas dari tingkat kedisiplinan yang diterapkan, dan perilaku bagi seluruh keluarga besar pondok pesantren. Mewujudkan ponpes yang berkarakter, dalam hal ini Pondok Pesantren Al- Halimy Sesela Lombok Barat menempatkan nilai disiplin pada posisi yang sangat penting untuk dikebangkan umum karena baik buruknya suatu sistem atau manajemen akan terlihat dari bagaiman kedisiplinan yang diterapkan. Terwujudnya kedisiplinan diri pada santri menjadi salah satu indikator bagi suatu lembaga pendidikan yang berkualitas.Adapun beberapa peraktik yang ditunjukkan oleh para santri sebagai wujud kedisiplinan diri seperti, datang ke madrastah sebelum jadwal pelajaran dimulai, menggunakan seragam sesuai ketentuan yang sudah ditetapkan oleh madrastah, mengikuti semua rangkaian pondok pesantren, dan kesemuanya ini terggambar 
dalam ungkapan salah seorang informan yang peneliti wawancarai sebagai berikut:

"biasanya kami sudah berada di madrasah 15 menit sebelum pelajaran dimulai, ya kiri-kira pukul 06.45 kami sudah berada pada lingkungan pondok pesantren, selambat-lambatnya pukul 07.00, dan pada malam harinya rata-rata kami sudah mempersiapkan buku pelajaran besok paginya, sehingga tidak terlalu banyak kesibukan di pagi hari, makanya jarang ada yang terlambat datang kemadrastah. Selanjutnya ketika berada di madratsah, sudah siap untuk mengikuti rangkaian kegiatan sebelum masuk keruang kelas,yaitu berbaris dilapangan,kemudian latihan pidato yang sudah terjadwal secara bergantian dari perwakilan masing-masing kelas,menyanyikan salah satu lagu islami,kemudian yang terakhir adalah doa, diantaranya membaca doa salawat do'aiyah atau membaca asmaul husna, baru kemudian kita masuk kelas masing-masing"

Berdasarkan pengakuan salah satu santri tersebut, cukup mencerminkan kedisiplinan diri santri sudah terbentuk melalui pembiasaan-pembiasaan yang di terapkan dalam pondok pesantren. Sepertinya kebiasaan itu sudah terpolarisasi melalui berbagai kegiatan yang diprogramkan oleh pondok pesantren.Di sisi lain terujinya kedisiplinan diri para santri akan terlihat dari bagaimana dia menerapkan kedisiplinan yang ditunjukkan dalan lingkungan pondok pesantren juga sama dengan apa yang ditunjukkan diluar lingkungan pondok pesantren.Menyusuri kedalaman peraktek kedisiplinan diri santri yang ditunjukkan di lingkungan pondok pesantren Al-Halimy Sesela Lombok Barat,peneliti juga menemukan hal- hal yang menarik misalnya,tidak ada santri yang keluyuran keluar masuk kelas ketika jam pelajaran berlangsung, Para ustadz dan ustadzah juga mengakhiri jam pelajaran tepat waktu, jam keluar main betul-betul dimamfaatkan untuk bermain dan belanja sesuai kebutuhan masing-masing.

Berdasarkan hasil pengamatan yang peneliti lakukan bahwa memang sangat jarang sekali santri maupun santri wati yang terlambat datang kesekolah hampir semua datang tepat pada waktu yang sudah di tentukan, karena jika ada yang terlambat mereka akan di hukum sesuai dengan ketentuan yang berlaku dari pondok pesantren. Para santri menunjukkan kedisiplinan yang patut dicontoh walaupun masih ada yang kurang menyadari akan 
pentingnya kedisiplinan diri tersebut.Internalisasi nilai kedisiplinan diri santri, sudah menjadi program unggulan dalam Pondok Pesantren Al-Halimy Sesela Lombok Barat, terbukti dengan terwujudnya ketertiban dalam proses belajar mengajar di lingkungan pondok pesantren al-halimy sesela Lombok barat. Kondusipitas suasana belajar tentunya juga merupakan imflikasi dari terbentuknya kedisiplinan diri santri dan pengelola pondok pesantren.

Pondok pesantren Al-Halimy Sesela dalam perjalanannya terus melaakukan ikhtiar untuk meningkatkan nilai kedisiplinan diri bagi santri dan segenap ustadz, pegawai dan setap yang ada dalam lingkungan Pondok Pesantren Al-Halimy Sesela Lombok Barat, sehingga kedisiplinan bagi para santri adalah suatu hal yang niscaya untuk di terapakan dalam lingkungan Pondok Pesantren AlHalimy Sesela Lombok Barat.Salah satu maslah yang selalu menjadi kendala bagi pondok pesantren dalam menarik simpati masyarakat adalah masih banyaknya pondok pesantren yang tidak terkontrol terutama untuk waktu belajarnya. Begitu juga halnya dengan Pondok Pesantren Al-Halimy Sesela Lombok Barat dalam menerapkan kedisiplinan santri mengalami berbagai kesuulitan, sehingga sedikit lamabat dalam perkembangannya. Tapi galiat perkembangan Pondok Pesantren Al-Halimy Sesela Lombok Barat ini terlihat sejak mulai ditingkatkanya kedisiplinan santri.

\section{Kecakapan Emosional}

\section{Saling Membantu}

Budaya saling membantu antar sesama santri sangat mewarnai lingkungan Pondok Pesantren Al-Halimy Sesela Lombok Barat, ketika ada salah satu temen mereka yang mengalami kesulitan dalam memahami pelajaran mereka langsung berdiskusi untuk membantu menyelesaikan kesulitan yang di hadapi oleh temannya itu, juga dalam hal-hal yang lain mereka salalu saling bahu membahu dalam setiap maslah yang mereka hadapi, apalagi kalao ada tugas yang dibebankan oleh para ustadz mereka lansung bekerja 
sama uuntuk menyelesaikannya. Hal ini tergambar dari pengaakuan salah seorang santri yang peneliti wawancarai sebagai berikut.

"Kami disini selalu saling membantu dalam setiap masalah yang dihadapi oleh teman-teman kita, dan ini sudah menjadi budaya yang dikembangkan di pondok pesantren ini sejak dulu, sehingga jika ada teman kita yang kesusahan maka semua juga merasakan esusahannya. Para ustadz dan ustadzah juga selalu mengingatkan kepada kkami semua untuk senantiasa saling membantu dalam setiap permasalahan yang di hadapi oleh teman-teman disini."

\section{Keadilan}

Perilaku yang bisa ditunjukkan oleh para ustadz di Pondok Pesantren Al- Halimy Sesela Lombok Barat adalah berlaku adil kepada seluruh santri tanpa membedakan mereka berdasarkan jenis kelamin dan setatus sosial mereka, ini di maksudkan agar bisa dijadikan contoh dan suri tauladan yang baik oleh para santri dan santri wati. Berlaku adiil menurut ustadz adalah keharusan yang terbiasa sejak dini, sehingga tidak ada yang akan merasa kecewa atas tindakan yang kita ambil. Penjelasan ini di perkuat oleh setatemen tuan guru sebagai berikut:

"Tidak ada alasan bagi kami selaku pengelola sebuah lembaga pendidikan, lebih-lebih ini adalah pondok pesantren untuk tidak berlaku adil kepada semua santri yang kami bina disini, bagaimana mungkin mereka bisa menjadi anak yang baik jika kami sendiri tidak mengajarkan dan melatih mereka melakukan hal-hal yang baik seperti melakukan berlaku adil, tolong menolong, saling menghormati, dan lain sebagainya. Sehingga kami di dalam memberikan hadiah maupun hukuman tidak pandang bulu, yang berprestasi diberikan hadiah sesuai dengan ketentuannya, begitu juga halnya dengan yang berbuat salahakan dihukum sesuai dengan ketentuan yang berlaku."

Berlaku adil kepada semua santri sudah menjadi ciri khas yang di tunjukkan oleh semua penghasuh dan tenaga pendidik di Pondok Pesantren Al-Halimy Sesela Lombok Barat, terlebih dalam memberikan penilaian atas prestasi santi dan santri wati tetap mengedepankan obyektifitas atas dasar keadilan, karena tanpa berbuat adil, kemajuan suatu lembaga pendidikan akan menjadi suatu hal yang mustahil dicapai, untuk itu lah para pengelola 
Pondok Pesaantren Al-Halimy Sesela Lombok Barat selalu mengedepankan konsep keadilan kepada semua santri dan para pengelola pondok pesantren tanpa memandang bulu dan setatus sosial mereka. Hal ini diperkuat oleh pengakuan sakah seorang santri yang peneliti wawancarai sebagai berikut:

"Selama ini,kami belum pernah merasakan perlakuan yang tidak adil dari para ustadz kami di sini, yang pintar ia mendapat juara dan hadiah,bagi yang tidak pintar selalu diberikan motipasi untuk semakin giat belajar supaya bisa menyamai teman-teman yang sudah berprestasi,tanpa memandag bulu, atau kekayaan kami, kami semua dianggap sama dan diperlakukan sama, makanya kami sangat senag sekali berada di pondok pesantren ini dan kami berharap pondok kami semakin jaya sepanjang masa"

\section{Toleransi}

Umumnya pondok pesantren yang masih tergolong tradisional berpegang pada aqidah ahlussunah wal jamaah tak terkecuali Pondok Pesantren Al-Halimy Sesela Lombok Batar, dalam peraktiknya di ajarkan kitab-kitab yang beraliran ahlussunah waljamaah, karena engan demikian para santri bisa memiliki nilai toleransi yang tinggi, ujud toleransi yang di peraktekkan, oleh para santri Pondok Pesantren Al-Halimy Sesela Lombok Barat adalah tidak membeda-bedakan sama siapa dia bergaul, berintraksi, berdiskusi, baik dalam lingkungan ponpes maupun lingkungan masyarakat, bahkan luar agama pun mereka tidak pernaha menutupi diri untuk berkomunkasi.Sikap toleransi inilah yang di yakini oleh Pondok Pesantren Al-Halimy Sesela,bisa meredam berbagai konplik horizontal baik dari segi agama maupun sosial politik.Bersikap dewasa dan toleran merupakan wujud dari implementasi rasa hormat terhadap orang lain atas segala perbedaan yang ada. Santri ponpes al-halimy sesela selalu welcome terhadap segala perbedaan yang ada, hal ini di buktikan denganmudah nya para santri Pondok Pesantren Al- Halimy Sesela dalam beradaptasi dengan lingkunganluar pondok pesantren, misalkan ketika ada kegiatan-kegiatan yang diadakan diluar 
lingkungan pondok pesantren,sebagai penuturan salah satu pengasuh sebagai berikut:

"Saya sebagai Pembina peramuka di sini, merasa sangat bangga melihat sikap mental dana rasa toleransi yang ditunjukan oleh santri kita di sini, saya sering perhatikan ketika ada latihan perramuka gabungan tingkat kabupaten maupun tingkat provensi, disana akan mereka bertemu dengan siswa/siswi dari berbagai sekolah yang tentunya memiliki karakter dan latar belakang yag berbeda, tapi walaupun demikian mereka tidak pernah merasa canggung dan rendah diri, dan juga tidak pernah menyombongkan diri,mereka bergaul dengan wajar dan saling menghormati satu sama lain, sehingga jarang sekali kami menemukan adanya konflik yang berbahaya"

Menanamkan sikap toleransi kepada santri adalah merupakan bagian yang tidak kalah pentingnya, sebagai bentuk implementasi pengembangan karakter. Adapun model nilai toleransi yang dikembangkan dalam pondok pesantren al- halimy sesela adalah seperti saling menghargai walaupun berbeda pendapat, mengakomodir semua perbedaan yang ada, menganggap perbedaan menjadi suatu rahmat yang patut di syukuri, kesemuanya ini menjadi cirri khas yag mewarnai kehidupan Pondok Pesantren Al-Halimy Sesela Lombok Barat.

\section{Kecakapan sepiritual}

Kecakapan sepiritual dalam pondok pesantren al-halimy sesela dijadikan sebagai sumber yang mengilhami dan melambangkan semanagat para santri melalui pedekatan mengikatkan diri pada nilaai-nilai kebeneran tanpa batas waaktu. Peraktik-peraktik yang dijadikan sebagai pemmbuktian dalam proses perkembangan kecakapan sepiritual seperti, membiasakan santri untuk sholat berjamaah sebelum pulang sekolah, menunaikan sholat sunat dhuha setiap pagi dan puasa sunnah setiap hari senin dan kamis serta berharap amallan keagamaan lianya yang menunjang pembentukan karakter santri.

Harapan besaara yang ditanamkan oleh Pondok Pesantren AlHalimy Sesela dalam mengembangkan kecakapan spiritual adalahh terlahirnya santri-santri yang memiliki prinsip dan visi yang kuat, 
mengakarnya nilai toleransi yang tertanam dalam hati santri, sehingga mampu melihat perbedaan menjjadi potensi yang perlu dikembangkan, dan memiliki rasa hirao terhadap setiap sisi kehidupan, serta memiliki kemampuan untuk bertahan dalam kesulitan dan penderitaan.Pentingnya percakapan spiritual untuk dimiliki oleh setiap santri terlihat dari upaya serius yang dilakukan oleh para Ustadz/Ustadzah di pondok pesaantren AlHalimy Sesela Gunung Sari Lombok Barat,dengan harapan setelah menamatkan belajar di pondok pesantren al-halimy sesela setiap santri memiliki bekal keperibadian yang bisa mengantarkan mereka menjadi manusia yang bermanfaat bagi orang lain, minimal bagi dirinya sendiri. Berikut petikan wawancara yang peneliti lakukan:

"Yang dibutuhkan oleh seseorang bukan hanya kecerdasan intelektual saja, namun yang paling penting adalah bagaimana mereka memiliki kecerdasan spiritual yang akan mendekatkan mereka dengan Tuhan, dan itulah yang akan menjadi suatu yang bermanfaat untuk kehidupan kelak, jadi itulah sebabnya kami disini selalu menekankan pentingnya bagi mereka untuk mendekatkan diri pada Tuhan dengan berbagai cara yang bisa mereka lakukan, seperti sholat berjamaah lima waktu, berpuasas dan lain sebagainya, yang kesemuanya ini di harapkan menjadi bekalnya kelak di akhirat"

Dukungan dari lingkungan pondok pesantren menjadi sangat penting dalam mencapai target dan tujuann pondok pesantren dalam mengujudkan Visi, misa yyang sudah ditentukan. Melatih santri dalam Dalam melakukan kebaikan memang suatu hal yang tidak mudah, tapi harus dilatih secara terus menerus dan konsisten. Pembiasaan sholat berjamaah sebelum pulang sekolah adalah hal yang sangat positif untuk membentuk karakter santri menjadi manusia yang bermartabat.Program sholat dhuha menjadi salah satu program unggulan yang ditawarkan oleh pondok pesantren alhalimy sesela, para santri sudah terbiasa melaksanakan sholat dhuha setiap hari, tanpa di perintah oleh para ustadz ketika pada waktu sholat berjamaah para santri langsung menuju masjid pondok untuk menunaikan sholat dhuha, dan setealah selesai menunaikan sholat dhuha para santri melakukan diskusi dengan sistem 
membentuk kelompok-kelompok kecil selama libih kurang 15 menit, kemudian setelah itu kembali masuk kelas masing- masing. Sholat dhuha ini diyakini sebagaai suatu ibadah yang dapat mempermudah datangnya rizeki, lebih-lebih dilakakan oleh para penuntut ilmu. Menyalaraskan anatara doa dan ikhtiyar merupakan arahan yang selalu dikembangkan dalam lingkungan pondok pesantren. Menurut pendapat salah seorang ustadz dalam menilai kebiasaan sholat dhuha sebagai berikut:

"sholat dhuha ini adalah suatu ibadah pamungkas terutama bagi para penuntut ilmu, karena disamping menuntut ilmu, rizki juga menjadi aspek pendukung lancarnya proses menuntut ilmu, kan agama juga menyuruh kita untuk menyeimbangkan anatara dunia dan akhirat, ilmu dan rizki selalu menjadi satu kesatuan dalam setiap doa seseorang. Sehingga kami memprogramkan sholat dhuha setiap hari, tidak hanya bagi santri saja ttapi bagi seluruh ustadz dan ustadzah yang ada di pondok pesantren ini"

Neong Muhadajir dalam Mawardi Lubis (2011:18-19) membagi nilai menjadi 5 bagian yaitu: pertama, dilihat dari kemampuan jiwa manusia, nilai dibedakan menjadi dua kelompok: a)nilai yang setatis, seperti kognisi, emosi, konasi, dan psikomotor, dan b)nilai/kemampuan yang dinamik, seperti motif, berafiliasi, motif berkuasa, dan motif berprestasi. Kedua, berdasarkan pendekatan budaya manusia, nilai hidup dapat dibagi kedalam tujuh katagori: a)nilai ilmu pengetahuan,b)nilai ekonomi, c)nilai keindahan, d) nilai politik, e) nilai keagamaan,f) nilai kekeluargaan, dan g) nilai kejasmanian. Ketiga, nilai-nilai dilihat dari sumbernya terdapat dua jenis:a)nilai ilahiyah,b) nilai insaniyah.Niali ilahiyah adalah nilai yang bersumber dari agama (wahyu allah), sedangkan nilai insaniyah adalah nilai yang diciptakan oleh manusia atas dasar kriteria yang diciptakan oleh manusia pula. Keempat, dilihat dari dari segi lingkungan keberlakuannya, nilai dapat dibagi menjadi nilai-nilai universal, demikian pula ada nilai-nilai insaniyah yang brsifat universal. Dari segi keberlakuan masanya, nilai dapat dibagi menjadi: a) nilai abadi, b) nilai pasang surut, dan c) nilai temporal. Kelima, ditinajau dari segi hakekatnya, nilai dapat dibagi menjadi: a) nilai hakiki (root values) dan b) nilai instrumental. Niali-nilai yang 
hakiki ini bersifat universal dan abadi, sedangkan nilai-nilai instrumental dapat bersifat lokal, pasang surut, dan temporal.

Linda sebagaimana yang di kemukakan Zarqoni mengatakan bahwa nilai itu terdiri dari nilai nurani (velue of being) dan nilai memberi (value of giving). Nilai nurani adlah nilai yang berada pada diri manusia kemudian berkembang menjadi prilaku dan cara memperlakukan orang lain. Nilai ini terinfleksi dalam bentuk kejujuran, keberanian, cinta damai, kedisiplinan, tahu diri dan sebagainya. Sementara nilai memberi, yakni nilai yang perlu dipraktikkan kemudian akan diterima sebanyak orang yang diberikan. Nilai ini di antaranya dapat dipercaya, menghormati orang lain, peka, tidak egois, baik budi, ramah dan sebagainya (Zarqoni, 2012: 47).

Sampai di sini, maka pertanyaan selanjutnya adalah siapa yang memiliki otoritas dalam penentuan nilai-nilai karakter yang representatif untuk diimplementasikan tersebut? Lalu apa saja nilai-nilai karakter yang harus diimplementasikan dalam konteks pengembangan pendidikan karakter di Indinesia saat ini?

Degradasi moral yang menjadi isu sosial yang melanda negeri ini sesungguhnya menjadi embrio munculnya pendidikan karakter, maka penentuan nilai-nilai karakter sesungguhnya menjadi otoritas pemerintah yang secara langsung memiliki kepentingan dalam mengembangkan pendidikan karakter. Lalu nilai apa saja yang harus diimplementasikan dalam pengembangan pendidikan karakter saat ini? Persoalan ini pun harus bermura pada tujuan pendidikan karakter sendiri, yaitu nilai-nilai yang terindikasi mampu mendobrak degradasi moral yang menjadi persoalan bangsa ini.

Doni Koesoema Antonius (2010:12) merumuskan 8 nilai karakter yang dapat dijadikan sebagai kerangka pendidikan karakter di sekolah yaitu: (1) Manusia memiliki keutamaan jika ia menghayati dan melaksnakan tindakan-tindakan yang utama, yang membawa kebaikan bagi diri sendiri dan orang lain. Dalam konteks bernegara nilai keutamaan ini berupa sikap kepahlawanan, pengorbanan yang mementingkan kesatuan bangsa dari pada kepentingan kelompok; (2) Nilai keindahan terdeteksi dari dimensi 
interioritas manusia yaitu nilai religiusitas yang terintegrasi dalam kultur bangsa; (3) Kualitas dari seorang individu ditentukan dari atas nilai kerja keras yang dimiliki; (4) Nilai cinta tanah air merupakan karakter yang harus tetap terjaga dalam perkembangan pendidikan karakter. Nilai patriotisme menjadi ikatan batin seseorang terhadap tumpah darah; (5) Nilai demokrasi mempertemukan secara dialogis berbagai macam perbedaan dalam masyarakat hingga mampu membuat kesepakatan dan konsensus atas hal-hal yang berkaitan dengan kehidupan bersama; (6) Dalam konteks berbangsa dan benegara, nilai kesatuan menjadi dasar pendirian negara. Persatuan tidak dapt terwujud jika setiap individu tidak dapat menghormati perbedaan dan heterogenitas masyarakat; (7) Nilai moral akan lebih efektif jika nilai-nilai pancasila menjadi jiwa pendidikan karakter; (8) Nilai-nilai kemanusiaan sangat relevan diterapkan dalam pendidikan karakter karena bangsa ini telah menjadi masyarakat global, sehingga semangat kewarganegaraan dalam konteks lokal tidak lagi relevan untuk diterapkan.

\section{Catatan Akhir}

Nilai-nilai karakter yang marak diwacanakan oleh para ahli belakangan ini, sebenarnya telah diajarkan, ditanamkan dalam bingkai pendidikan Islam, di lembaga-lembaga pendidikan Islam sejak awal kehadirannya hingga saat ini. Tentunya, pendidikan karakter yang dimaksudkan adalah pendidikan karakter ala Islam yang memiliki kekhasan tersendiri yang berbeda dengan pendidikan karakter pada umumnya.

\section{Daftar Pustaka}

Agama RI, Departemen. Pola Pembelajaran di Pesantren. Jakarta: Departemen Agama RI, 2001.

Ali, A.Mukti. Beberapa Persoalan Agama Dewasa Ini. Jakarta: Rajawali Press, 1987.

Arifin, Imron. Kepemimpinan Kyai, Kasus Pondok Pesantren Tebuireng, Malang: Kali masyahada Press, 1993. 
Arikanto Suharsimi. Prosedur Penelitian Suatu Pendekatan Praktek. Jakarta: Rineka Cipta, 2006.

Asrori, Psikologi Pembelajaran ,Bandung: CV.Wacana Prima, 2008

Dharma Kesuma dkk, Pendidikan Karakter: Kajian Teori dan Praktek di Sekolah, Bandung: Remaja Rosdakarya,2011.

Doni Koesuma Antonius, Pendidikan Karakter:Strategi Mendidik Anak di zaman Global. Jakarta: Grafindo, 2010.

Hidayatullah, Pendidikan Karakter Membangun Peradaban Bangsa.

Surakarta: Yuma Pustaka, 2010

M. Arifin dan Barmawi. Strategi dan Kebijakan Pendidikan Karakter. Yogyakarta:Ar-Ruzz Media 2012.

Majid Abdul dan Dian Andayani, Pendidikan Karakter Perspektif Islam, Bandung: Remaja Rosdakarya, 2011.

Mustapa, Filsafat Islam, Bandung,:Pustaka Setia, 2009.

Samani Muchlas, dan Hariyanto, Konsep dan Model Karakter, Bandung: Remaja Rosdakarya, 2011.

Sulthon, Mashud dan Moh. Khusnurdilo. Manjemen Pondok Pesantren. Jakarta: Diva Pustaka, 2005.

Sunarti Euis, Mengasib Dengan Hati: Tantangan yang Menyenangkan, Jakarta: Elex Media Komputindo, 2004.

Suwito, Filsafat pendidikan akhlak ibn Miskawaih, Yogyakarta: Belukar, 2004.

Umar Bin Ạ̣mad Bārajā', Kitab Al-Akhlāq lil Banin Jilid Pertama, Surabaya: Maktabah Muhammad bin Ahmad Nabhān wa Aulädah 2004.

Wahyuni Seri Tanzil, Model Pembinaan Pendidikan Karakter Pada Lingkungan Pondok Pesantren dalam Membangun Kemandirian dan Disiplin Santri, dalam Jurnal Penelitian Pendidikan UPI, Vol. 13 No. 2 Oktober 2012.

Zahrudin dan Hasanudin, Sinaga, Pengantar Studi Aqidah Akblak. Jakarta: Raja Wali Press, 2004 